\section{The light and the dark}

\section{Lewis Thomas}

The Limits of Science. By P.B. Medawar.

Harper \& Row: 1984. Pp. 102. \$11.50.

To be published in Britain in February 1985 by Oxford University Press.

THESE are hard days for science, for all the achievements of the past two or three centuries that have made possible the lives of vast numbers of human beings who would never, without the works of science, have survived the population curve that now seems to be turning into a sustained near-vertical upswing. Food production on a scale sufficient to have kept most such populations from crashing long since, medical and public health advances that have nearly doubled the possible life expectancy in affluent nations in just this century, technologies for communication that ought to be offering the prospect of world-wide education for all people, not to mention diversion and entertainment - these are among the contributions of basic scientific research and its companion art, applied science. More than these, science's greatest contribution to humanity has been the beginning of something like a comprehension of the true nature of Nature, in a range extending from the most intimate and essential transactions within a single living cell down to the fundamental nature of atoms and their particles, and out to the furthermost reaches of the Cosmos and, perhaps, some of the detailed events of the birth of the Universe itself.

No doubt about it: science is, as Peter Medawar asserts in the preface to his latest and, in my view, most wonderful book, "a great and glorious enterprise - the most successful . . . that human beings have ever engaged in".

But it is not seen this way by everyone, most certainly not by a great many thoughtful, well-educated, worried men and women in the streets of the world. To the contrary, science is widely perceived as the root cause of our most intractable problems: the population explosion itself, the detachment of humankind from all the rest of nature, the despoliation of the environment, the loss of any sense of mystery about the world and the way it works, the flattening out of human experience. And now, since the Second World War, the worst of things ever done by science, the overhanging threat to the planet of thermonuclear weaponry.

The Limits of Science does not settle the dispute, but it does do something almost as important, perhaps more important than winning an argument. It lays out the issues at stake, fairly and gracefully. Medawar is wholly on the side of science, he gives no ground, he is determined and firm in his views. In the first third of his book, a chapter titled "The Nature of Scians", he moves freely from one large topic to another, briefly and aphoristically, the whole intended to provide the reader with information needed for an understanding of what science really is, how it is carried out, and what makes it work when it luckily does work. In one paragraph headed

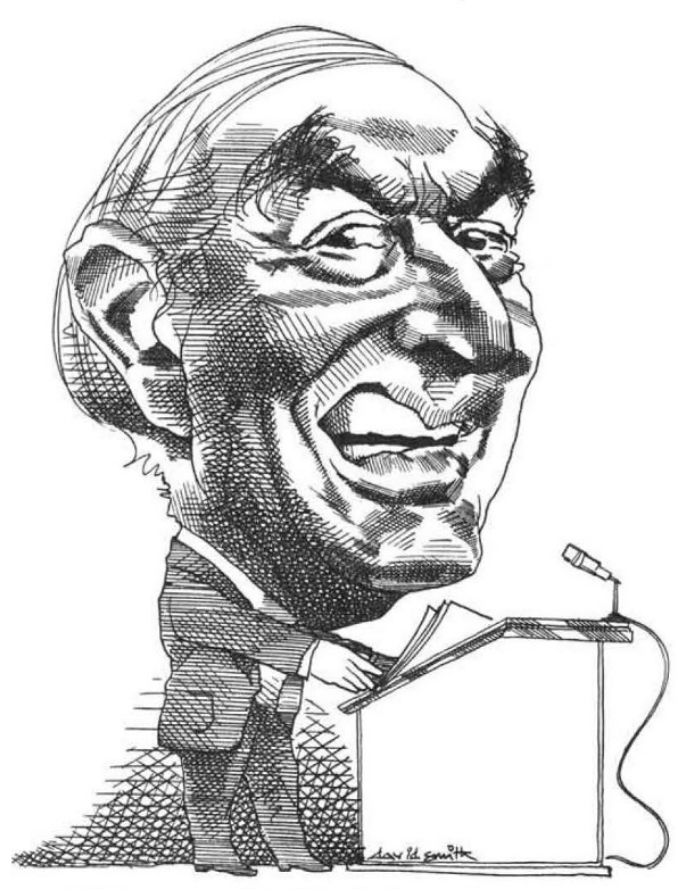

"Science and Politics", he writes,

Some of my colleagues will think me sensible, others disloyal, when I roundly declare that political and administrative problems are not in general scientific in character, so that a scientific education or a successful research career do not equip one to solve them . . . . More than that, I regard my opinions as so obviously right as not to be worth the exertion of justifying them.

But then, he goes on justifying in several pages of historical instances in which politicians and statesmen should have found scientific knowledge indispensable for making decisions affecting the public welfare, including this one:

I have never met a scientist who does not believe that the effects of ionizing radiations from a nuclear bomb, especially upon deoxyribonucleic acid, the vector of genetic information, are so utterly frightful as to outweigh all other considerations in framing national policy, among which I include national pride (the chap inside is past caring whose flag flies over his tomb).

I must say that I have run into a scientist or two or three lacking such belief, but I agree that they are the rare exceptions.

The first two of the three chapters that comprise this compact book are vintage Medawar, so much fun to read that you may fail to recognize, until later, that he is writing seriously on serious matters, doing his best to protect scientific endeavour against damage by people (and governments) who have an insufficient grasp of the importance of the enterprise. He keeps coming back to his main point: "In terms of the fulfillment of declared intentions, science is incomparably the most successful enterprise human beings have ever engaged upon".

And then, in the last 40 pages, he moves into new, darker territory. What are the questions that lie forever beyond the reach of science, for which the answers can never be stated flatly in scientific, testable, verifiable or falsifiable sentences? They are, he says, the questions about first things and last things: How did everything begin? What are we all here for? What is the point of living? Is there a God? Queries such as these, says Medawar, are no part of science's business. Not that they cannot be answered, he concludes, just that the answers are by their nature matters of faith, not matters accessible to reason.

He loses me, or I him, in his last pages. He defines "religion", and then sets it aside, as a set of explanations that

appeal to the agency of a personal God and I should have insisted upon the notion of a personal God, for nothing could be more wishy-washy or generally unsatisfying than to liken God to some kind of diffuse benevolence that permeates the material world.

I do wish that Medawar, one of the most spectacular biologists of the century, in possession of one of the clearest minds, more acutely aware than most of his colleagues of the immense amount of biological and physical science still out there, waiting to be discovered, filled with mystery because still so unknown, had not left it there. Stick around, I claim, keep an eye on surprise. Maybe not the very first things, or the very last things, but some very early and very late things are waiting to be tripped over, and tripped over most likely by science.

But Medawar succeeds anyway, despite my kind of doubt and misgiving. He takes up important matters, honestly and in high courage. His book should be read and welcomed by scientists, especially young scientists just starting out, and by a nonscientist public wanting a better understanding of how a scientific mind works in high gear. In short, by just about everyone I can think of.

Lewis Thomas is President Emeritus of the Memorial Sloan-Kettering Cancer Center, New York. 